\title{
Correction to: Comparing engagement by migrants in domestic and in country-of-origin political activities across European cities
}

\author{
Katia Pilati ${ }^{1}$ - Barbara Herman ${ }^{2,3}$
}

Published online: 26 November 2019

(c) The Author(s) 2019

\section{Correction to: Acta Polit https://doi.org/10.1057/s41269-018-0102-4}

The article Comparing engagement by migrants in domestic and in country-of-origin political activities across European cities, written by Katia Pilati and Barbara Herman, was originally published electronically on the publisher's internet portal on 16 July 2018 without open access. With the author(s)' decision to opt for Open Choice the copyright of the article changed on 21 November 2019 to (C) The Author(s) 2018 and the article is forthwith distributed under a Creative Commons Attribution 4.0 International License (https://creativecommons.org/licenses/by/4.0/), which permits use, sharing, adaptation, distribution and reproduction in any medium or format, as long as you give appropriate credit to the original author(s) and the source, provide a link to the Creative Commons licence, and indicate if changes were made.

The original article has been corrected.

Open Access This article is distributed under the terms of the Creative Commons Attribution 4.0 International License (http://creativecommons.org/licenses/by/4.0/), which permits unrestricted use, distribution, and reproduction in any medium, provided you give appropriate credit to the original author(s) and the source, provide a link to the Creative Commons license, and indicate if changes were made.

The original article can be found online at https://doi.org/10.1057/s41269-018-0102-4.

Katia Pilati

katia.pilati@unitn.it

1 Department of Sociology and Social Research, University of Trento, Via Verdi 26, 38122 Trento, Italy

2 Chargée de Missions - CRAcs, Centre Bruxellois d'Action Interculturelle, 24, Avenue de Stalingrad, 1000 Brussels, Belgium

3 Group of research on Ethnic Relations, Migration and Equality (GERME), Université Libre de Bruxelles (ULB), Brussels, Belgium 